\title{
AN EXPLORATORY STUDY OF SELF-CONTROL PROBLEMS AND EATING BEHAVIOR
}

\author{
Dalma PETŐ \\ Institute of Business Studies, University of Szeged, Hungary
}

Received: 29. August 2020, Reviewed: 13. October 2020, Accepted: 20. November 2020

\begin{abstract}
Malnutrition and obesity can be a source of many diseases, such as cancer or cardiovascular disease, especially when combined with unhealthy lifestyles. It would be rational if the individual's consumption decisions would take into account the long-term health consequences of their decisions, thus avoiding diseases caused by unhealthy eating and saving medical and pharmaceutical costs for the future. Studying young age group's nutrition decisions is important as they will be the workers and consumers of the future. In our research, we are looking for the answer to what level of self-control young consumers have and how this affects their diet. To answer this question, we conducted a questionnaire survey based on the Tangney - Baumeister - Boone self-control scale and the Dutch Eating Behavior Questionnaire (DEBQ) in Hungary. Based on the results, we found that individuals with weak self-control are more likely to eat under the influence of emotions or external factors. Individuals with strong self-control are characterized by restrain eating behavior.
\end{abstract}

Keywords: healthy nutrition, young adults, self control

JEL Classification: M31, I12, P36

\section{Introduction}

Nutrition affects our entire life from the beginning of our childhood. Our eating habits develop very early on and affect our health. Improper nutrition can affect our entire life or even shorten it. Therefore, it is important to pay attention to the development of appropriate eating habits already in childhood (Huszka \& Dernóczy, 2015).

A healthy diet, paying special attention to the consumption of vegetables and fruits, helps to get the right amount and quality of nutrients into our body, along with filling it with vitamins. However, unfortunately, the diet of all age groups differs from the recommended: they consume less vegetables and fruits, but more energyrich, poor-quality foods (Black et al., 2017).

Malnutrition can be the source of many diseases caused by obesity. Such diseases are cancer or cardiovascular diseases, mainly associated with unhealthy lifestyles. The health status of the population is only partially influenced by healthcare, 
the role of lifestyle (with nutrition) is significant. An increasing proportion of the Hungarian population is obese. In Hungary, cardiovascular diseases are responsible for half of the deaths. The second most common deaths are caused by cancers, and gastrointestinal diseases also cause the deaths of many people (KSH, 2017).

The first signs of many chronic diseases (such as cardiovascular disease, diabetes, obesity) can be detected as early as childhood (Black et al., 2017). In addition, psychological illnesses such as depression are also associated with obesity, which means an even worse quality of life for the person (Vazquez \& Torres-Iglesias, 2012). According to a study involving children and young people between the ages of 2 and 19 , obesity that begins at a young age is much more likely to cause fatal illness than if obesity develops only in adulthood. In this case, the chances of type 2 diabetes, hypertension, and cardiovascular disease also increase significantly (Park et al., 2012). However, not only long-term but also short-term consequences can be expected, as pathological obesity already causes health problems in the short term (Reilly \& Kelly, 2011).

We run into difficulties studying health as a value in economics because we are not talking about a typical goods that has a definite price or market value. In the same way, it is not possible to quantify the number of healthy years spent and the extra years of life (Lippai, 2012).

The level of health care expenditures is increasing year by year. Examining the data on domestic health expenditure, we can see that households are spending more and more money for this purpose in Hungary as well, especially for medicines, medical aids and other medical goods (KSH, 2017).

The study of healthy eating for the young age group is of paramount importance as they will be the workers and consumers of the future (Drabik et al, 2020). Although they do not yet have their own earnings, they make their own decisions about their daily diet and are old enough to even cook for themselves. In our research, we look for the answer to what level of self-control young consumers have and how this affects their eating habits. In the present study, we examine their eating behavior. As a theoretical framework for the study of this topic, we chose a specific field of behavioral economics, intertemporal bias, and within this, the effect of limited selfcontrol on consumption.

\section{Bounded rationality}

In order to examine the issue, we must definitely address the concept of rationality. Assuming a rational consumer, everyone would choose healthy foods, as this decision will largely determine their future health.

Classical economic models assume rational consumers who seek to maximize their benefits. This is also true of homo oeconomicus, which satisfies only the necessities of existence, but the motivations of the actions of a person living in "well-being" are much more driven by emotions (Székely, 2003). The reason for assuming rationality is that this makes economic interactions easier to examine. According to Friedman (1986), if we look at these interactions in an aggregate way, the irrational behavior of each actor does not affect the results, so we may be able to make assumptions about the future (Friedman, 1986).

However, rationality is often lack in real economic decisions, and the reason for this can be found in the decision-making process, which consists of a number of factors such as perception, influence, motivation and preference (McFadden, 1999). Consumers often do not choose the optimal one because they make a mistake or do 
not have adequate self-control to make a rational decision (Mulvaney \& Lee 2017). For example, if a dieter is offered a cake, their long-term goals say they won't accept it, yet they may accept it. This weakness of will appears in the short-term desire to overcome the long-term (Elster, 2001).

According to Herbert Simon (1986), the creator of the theory of bounded rationality, we should not be concerned with how economic actors should behave, but with how they actually act. He draws attention to three main shortcomings of neoclassical rationality theories. Neoclassicals do not take into account consumer preferences and values; assume consistent behavior; and the time dimension is not taken into account in decision-making situations (Simon, 1986). The theory of bounded rationality does not seek to abolish neoclassical models of rationality, but rather to supplement it (Golovics, 2015). After all, bounded rationality also presupposes that people act rationally, but their cognitive and emotional qualities influence their decisions (Jones, 1999). "Thus, we do not examine emotions and other unconventional attitudes against rationality, but try to prove that these additional motivations -which also have a role in economic processes and events, - they do not make it impossible to investigate on the basis of reason, they do not cover up the basic connections, they only modify and color them. However, these colors can become very important when studying certain economic phenomena" (Hámori, 1998, p. 25).

In the case of nutrition, rational behavior would be the choice of healthy alternatives, however, consumers do not always do so. As can be seen from the above, they do not necessarily act irrationally, they only decide within the limits of their cognitive and emotional characteristics.

\section{Intertemporal decisions}

A cognitive barrier in choosing unhealthy foods can be the problem of intertemporal decisions, as unhealthy food is often finer, more desirable, perhaps cheaper, or more readily available. Thus, the benefits of consuming unhealthy food are realized immediately by the consumer, while the associated expenses (problems) only appear later in time. "Intertemporal situations are often described in economic research as a choice between a 'short-term tempting / long-term disadvantageous' and a 'shortterm disadvantageous / long-term beneficial' alternatives." (Lippai, 2010, p. 6). These decisions are choices that will have an impact in the future (Berns et al., 2007).

For nearly 80 years, economists have used the discounted utility model to examine intertemporal decisions. The model assumes that people value the joy and pain of their decisions in the same way that financial markets value gains and losses, exponentially discounting the value of the outcome depending on how late it occurs in time (Berns et al., 2007). The discounted utility model attempts to model the psychological factors behind intertemporal decisions, where the discount rate is constant (Bölcskei, 2009). George Ainslie (1975) was the first to question the validity of the discounted utility model. According to him, the discount rate should be exponential (Ainslie, 1975). The most accepted model is the hyperbolic discounting model, which explains intertemporal decisions much better in the light of self-control problems (Bölcskei, 2009). According to Elster (2001, in Lippai 2010, p. 55), "consumer selfcontrol can be defined as one of the possible explanatory principles of anomalies in intertemporal consumer decisions relative to the expected (rational) outcome, which is basically two irrational forms of consumer behavior (?) / heuristics (?) refers to: myopia and procrastination. This approach also requires correction of the human image of homo oeconomicus, but leaves its basic axioms unchanged." 
To describe the self-control problem explained by the hyperbolic model, Fudenberg-Levine (2006) developed the double self model. The point is that individuals are both forward-thinking and planners and short-sighted actors. The planner self strives to maximize benefits in long-term, while the actor self acts in a selfish and short-sighted way. The source of the conflict is the conflicting interest. The planner self, however, seeks to encourage the acting self by using incentives to change the preferences of the acting self, or by setting and controlling rules. For example, in the case of dieting, it checks every month how much the individual has lost. In the case of dieting, it can also be a solution if the planner self does not limit the possibilities of the acting self to a single action, but only limits them, reduces them (Bölcskei, 2009).

Also, the model created to explain self-control problems associated with intertemporal decisions is the model of desire for commitment. The essence of GulPesendorfer's (1955, in Bölcskei, 2009) model is that the individual limits his or her choices, thus trying to exercise self-control and resist temptation. If you have high self-control, you will choose the alternative that has higher utility in the long run.

The willpower model is also used to model self-control problems related to intertemporal decisions (Ozdenoren et al., 2006 in Bölcskei, 2009). The model is explained by a simple example of cake consumption. Using the discounted utility model, the individual consumes the cake at a steady rate. In reality, however, this often happens when an individual consumes an increasing amount of cake, but this cannot be explained by either the hyperbolic or the double self model, only by the willpower model. This model simultaneously explains "present-distorted preferences, preference change, need for commitment, and preferences for a growing line of consumption" (Bölcskei, 2009). According to the model, earlier cognitive exertion has an effect on later consumption as willpower decreased. But it is also conceivable to leave the best to the end, so a negative preference is realized. Also, the individual often tends to link two actions that require self-control, such as quitting smoking and eating. He gives up smoking, but in the meantime allows himself to be seduced and eat more than he needs to. "The consumer exercises his willpower when it has the lowest opportunity cost, that is, when it has a large willpower and before it runs out over time, so the indirect marginal benefit of increased consumption increases over time." (Bölcskei, 2009).

\section{Obesity as a self-control problem}

The relationship between nutrition and self-control has also been researched by a number of researchers, with the main focus on obesity. Looking at the last 50 years, we can see that due to the development of technology, food prices have been falling, while the intensity of movement has fallen due to more and more sedentary work. Obesity is mainly due to these causes (Lakdawalla \& Philipson, 2002). Thanks to technology, work has also become more productive, allowing more and more tasks to be performed with less and less intensity and calorie burning, which also promotes obesity (Finkelstein et al., 2005). Although obesity can have a health cause, it can be seen that the main factor influencing obesity is an individual's personal lifestyle. Consequently, "the variable of self-control can play a very important role in the development of a form of behavior where consumers, fully aware of the benefits of exercise and the disadvantages of unhealthy eating, still lead unhealthy lifestyles." (Lippai 2010, p. 77).

According to Stutzer and Frey (2006), the cause of obesity is poor self-control and short-sightedness of the individual. It can be shown that if someone gets rid of more weight, it is easier to control their behavior. The source of the problem is that 
people face too many opportunities that have low immediate marginal costs but high long-term marginal benefits. Because of their lack of self-control, they turn to these opportunities with short-sightedness. They may be able to resist some temptation, but because of too many options, it is difficult to control their decisions. This is related to the willpower model mentioned above (Ozdenoren et al., 2006).

O'Donoghue and Rabin (2006) write in their research on the impact of "criminal taxes" that should be levied on unhealthy foods such as fatty foods due to their overconsumption. They examined how taxes levied on the consumption of unhealthy goods can be Pareto-effective so that it is optimal at all levels of self-control. According to classical economic models, there is no overconsumption as they act rationally. The reality, however, is that because of self-control problems, individuals often consume too much of unhealthy food. By doing so, they have a negative impact on their own health.

Self-control can play a role in several phases of a decision making situation. In problem identification, there may be a contradiction between the short and long term when defining future goals. But self-control is also needed in the search and evaluation of information to make the right choice. The consumer needs time to gather information, the lack of which often leads to impulse buying (Lippai, 2010).

Examining consumer self-control and examining consumer motivations can help create a preventive health policy that strengthens self-control in consumers about healthy eating. This could reduce health care spending in the future, as well as the burden on taxpayers.

\section{Eating behavior}

Eating behavior is considered to be the most important factor in the treatment and prevention of obesity and related diseases (Danielsen et al., 2013). According to psychosomatic theory, those who eat under the influence of emotions (fear, anger, anxiety) do not recognize this stimulus, and their calorie intake is higher (van Strien at el. 2016). Similarly, the external theory holds that the external environment determines eating behavior and that the appearance and smell of food brings out an overly strong reaction from overweight people (van Strien at el. 2016). The theory of restriction is also related to eating behavior, according to which during a diet, an individual consciously restrains food consumption in order to reduce or maintain body weight, which leads to a slowing of metabolic processes and a reduction in the feeling of hunger. However, as self-control decreases (e.g., under the influence of alcohol or negative emotions), cognitive restriction also decreases and eating behavior turns in the opposite direction, leading to excessive food intake. In addition, restricted eating can cause an individual to lose control of hunger and satiety, leading to emotional or external influences (Calvo et al., 2014).

Eating behaviors and attitudes have been the subject of numerous studies, and several measurement methods have been developed to investigate it. Garner and Garfinkel's (1979) Eating attitude test (EAT) can be used to examine mainly eating disorders. With the Herman and Polivy (1980) Restriction Scale, we can measure how consciously an individual limits food intake to limit his or her weight. This questionnaire provided the basis for the Three Factor Eating Behavior Questionnaire (TFEQ) (Stunkard \& Messick, 1985) and the Dutch Eating Behavior Questionnaire (DEBQ) (Van Strien et al., 1985). Both examine three eating behaviors: TFEQ distinguishes between uncontrolled eating, cognitive restriction, and emotional eating, and DEBQ distinguishes between restrained eating, emotional eating, and eating for external influences. 
In the present research, we used the Dutch Eating Behavior Questionnaire (DEBQ). A questionnaire designed to measure eating behavior that was developed in 1986 by van Strien et al. The questionnaire, originally consisting of 46 items, was later reduced to 33 questions, which have since been validated in several countries (including Brazil, China, Spain, France) (Moreira et al., 2017; Wu et al., 2017; Cebolla et al., 2013; Bailly et al., 2012).

The questionnaire examines eating behavior using three subscales. The external eating scale examines consumption under the influence of external stimuli associated with food, regardless of an individual's sense of hunger. The restrained eating scale measures whether an individual intentionally restrains their food intake to lose weight or prevent being overweight. The third, emotional eating scale, examines the effect of emotions (e.g., anger, tension, nervousness) on nutrition (Van Strien et al., 1986).

\section{Material and Methods}

In our empirical study, we examined the level of self-control of young people as well as their eating behavior in Hungary. We hypothesize that those with less selfcontrol are more likely to eat for emotional or external influences, while those with higher levels of self-control are characterized by restrained eating.

To measure self-control, we used the Tangney - Baumeister - Boone (2004) self-control scale, which is based on a psychological method to examine personality traits characteristic of self-control. The self-control scale of Tangney, Baumeister, and Boone (2004) consists of 36 items. It examines five dimensions of self-control (selfdiscipline, non-impulsivity, healthy habits, work ethic, and reliability). This self-control scale is widely known and has been adapted in many languages (French: Brevers et al., 2017; Chinese: Unger et al., 2016; German: Bertrams, 2009). It was first adapted to Hungarian language by Lippai (2010). The respondent should indicate on a 5-point Likert scale how true the statement is to him. Each statement is inversely coded, so this should be considered in the analysis. Adding the points given to the answers gives the self-control score of the given person.

To measure eating behavior, we used the above-mentioned Dutch Eating Behavior Questionnaire (DEBQ) to measure eating behavior.

The questionnaire survey was preceded by a small sample (30 people) trial survey, thus ensuring that the questions were understandable to everyone. The questionnaire was completed by a total of 529 people, the respondents were young people aged 18 to 23 university students.

The questionnaire was conducted both offline and online. Data collection lasted for 3 months. During this time, more than 700 answers were received. The questionnaire was distributed to as many young people as possible with the help of university lecturers, who helped to distribute the questionnaire among the students. The respondents were screened for 18-23 year olds. After data cleansing, 529 people remained in my sample.

$29.9 \%$ of the young people in the sample were men and $70.1 \%$ were women. $88.3 \%$ of them live in cities and only $12 \%$ of them live in a village or municipality (Figure 1.) 
Figure 1 Permanent residence of the sample

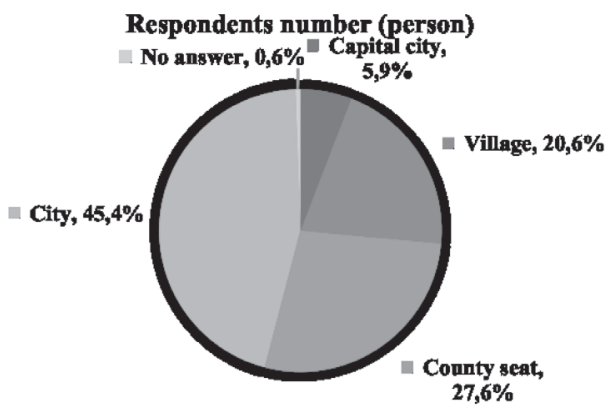

Source: own

\section{Results}

To examine the self-control scale, all variables were brought into the same form so that a higher score meant greater self-control everywhere and a lower score meant less self-control. We then examined the correlation of the variables with Cronbach's Alfa. Cronbach's Alpha was 0.833, indicating that our variables are consistent.

The minimum value measured by the self-control scale is 49 and the maximum is 134 . The mean of the scores is 81.45 and the standard deviation is 14 (Table 1).

Table 1 Mean and standard deviation of self-control scores

\begin{tabular}{|c|c|c|c|c|c|}
\hline \multirow{2}{*}{$\begin{array}{c}\text { Self-control } \\
\text { scores }\end{array}$} & $\begin{array}{c}\text { Respondents } \\
\text { number (person) }\end{array}$ & $\begin{array}{c}\text { Minimum } \\
\text { score }\end{array}$ & $\begin{array}{c}\text { Maximum } \\
\text { score }\end{array}$ & Mean & St.dev. \\
\cline { 2 - 6 } & 529 & 49.00 & 134.00 & 81.4556 & 14.00806 \\
\hline
\end{tabular}

Source: own

Three categories were developed from the self-control scale. Values in the +-1 standard deviation range from the mean were in the middle group, those with a lower score were in the weak self-control group, and those with a higher score were in the strong self-control group. With this grouping, 81 people have weak, 365 people have normal, and 83 people have strong self-control. The distribution of women and men is evenly distributed among each self-control category (Table 2.)

Table 2 Distribution of the sample by self-control categories

\begin{tabular}{|l|c|c|}
\hline Self-control categories & Respondents number (person) & Distribution (\%) \\
\hline Weak & 81 & 15,3 \\
\hline Normal & 365 & 69 \\
\hline Strong & 83 & 15,7 \\
\hline Total & 529 & $\mathbf{1 0 0}$ \\
\hline
\end{tabular}

Source: own 
Furthermore, from the questions of the DEBQ scale, we were able to create factors determined on the basis of the original scale, i.e. emotional eating, eating for external influences, and restrained eating factors with the help of factor analysis. Here, however, it is important to mention that, based on the responses of our respondents, we were only able to create these artificial variables without including some of the statements from the original variables in the factor analysis (Table 3.)

We also examined the Cronbach's Alpha value for the scales that make up each factor to see how well the variables correlate. Cronbach's Alpha was 0.953 for the emotional eating scale, 0.895 for the restrained eating scale, and 0.851 for the external effect scale, indicating that our variables are consistent.

\section{Table 3 Results of principal component analysis}

\section{DEBQ scale}

\begin{tabular}{|l|c|}
\hline KMO & 0,931 \\
\hline Bartlett test sig. value & $<0,05$ \\
\hline Cumulative variance ratio $(\mathbf{\%})$ & 59,036 \\
\hline Number of factors created $(\mathbf{d b})$ & 3 \\
\hline
\end{tabular}

Source: own

The self-control scale was then compared with eating behavior factors (Table 4). Positive values in the table indicate that those in the given self-control group are more affected by the given factor than all respondents in general, while negative values indicate that they are less affected by the given eating factor compared to the average. The larger the deviation from zero, the more significant this effect is. Thus, we can see that in our analysis, in line with our expectations, the eating habits of those with poor self-control are most affected by emotions and external stimuli. In contrast, individuals with strong self-control are not characterized by eating under the influence of either emotions or external influences, while restrain eating characterizes only them.

Table 4 Comparison of self-control level categories with eating behavior categories

\begin{tabular}{|l|c|c|c|}
\hline \multirow{2}{*}{$\begin{array}{l}\text { Self-control } \\
\text { categories }\end{array}$} & \multicolumn{3}{|c|}{ Eating behavior } \\
\cline { 2 - 4 } & Emotional eating & Restrain eating & External eating \\
\hline Weak & $\mathbf{+ 0 , 4 3 8}$ & $-0,119$ & $\mathbf{+ 0 , 3 6 9}$ \\
\hline Normal & $+0,023$ & $-0,044$ & $+0,005$ \\
\hline Strong & $\mathbf{- 0 , 5 5 4}$ & $+0,323$ & $\mathbf{- 0 , 4 0 1}$ \\
\hline
\end{tabular}

Source: own

Those with moderate self-control also achieved the results we expected. The diet of those in this group is affected by both emotions and external influences, however, these effects do not appear much stronger than the average for either factor.

Based on these results, it can be said that (as we suspected) individuals with weak self-control are more likely to eat under the influence of emotions or external factors, and individuals with strong self-control easily resist delicious and tasty looking food and are really successful at dieting.

The same relationship was studied between BMI categories and eating behavior types (table 5.). Our results show that eating under the influence of emotions 
is most characteristic of obese people, as well as overweight. Moderate eating is most characteristic of the obese. This may be due to the fact that moderate eating can be strict and flexible, which is linked to the success of the diet (Westenhoefer et al. 2013). So obese people can be characterized by moderate eating, because they are constantly trying to diet (but this, as their weight shows, does not work for them).

Table 5 Comparison of BMI categories with eating behavior types

\begin{tabular}{|l|c|c|c|}
\hline \multirow{2}{*}{ BMI categories } & \multicolumn{3}{|c|}{ Eating behavior } \\
\cline { 2 - 4 } & Emotional eating & Restrain eating & External eating \\
\hline Skinny & $-0,104$ & $-\mathbf{0 , 5 1 4}$ & $+0,067$ \\
\hline Normal weight & $-0,050$ & $-0,007$ & $+0,026$ \\
\hline Overweight & $+0,137$ & $+0,251$ & $-0,174$ \\
\hline Obese & $+\mathbf{0 , 5 4 3}$ & $+\mathbf{0 , 4 0 1}$ & $-0,047$ \\
\hline Total & $-0,002$ & $-0,002$ & $+0,001$ \\
\hline
\end{tabular}

Source: own

\section{Discussion}

Classical economics assume rational consumer who always weighs the choices and always chooses the most optimal one. In practice, however, this is not the case. An individual's decisions are also influenced by his or her emotions, in our case, when making eating decisions.

When making eating decisions, we are often confronted with the problem of intertemporal bias, especially when it comes to consuming unhealthy foods. The individuals evaluate their current situation and decide on it, they do not take into account the negative effects of their decisions in the future. These decisions can also be influenced by their eating behavior, as they have poor self-control, they tend to consume more food due to emotions or external factors.

In our research, we sought for the answer whether there is a correlation between young people's level of self-control and their eating behavior. To answer this question, we conducted a questionnaire survey based on the Tangney - Baumeister Boone (2004) self-control scale and the Dutch Eating Behavior Questionnaire (DEBQ). We created three self-control level categories (weak, moderate, strong), which we compared with the three categories of eating behavior (emotional eating, restrained eating, and eating under external influence). Our results show that individuals with poor self-control are much more likely to consume more food as a result of heightened emotions, and when they see food that is desirable to them, they consume it regardless of whether their body is hungry or needs the extra calories.

Obese individuals are mostly characterized by eating under the influence of emotions, but also by restrain eating behavior. The latter may be explained by the fact that they are aware of their obesity and want to change it, so they try to restrain their diet. 


\section{Conclusion}

The results of this study may be useful for obesity prevention campaigns. In our opinion, it would be worthwhile to introduce consumers to the theory of types of eating behaviors, because if they were aware of the effects that affect them personally in their diet, they could easier pay attention to prepare for such situations and practice greater self-control. It would be worthwhile to take an online software-based self-filling test to help everyone find out which types of eating behaviors are most typical of them. The limitation of our research is the unrepresentative sample, the respondents do not describe the population studied, but it provides a good starting point for the examination of correlations.

It would be worthwhile in the future to conduct research on other samples, as well as to examine in more detail the relationship between people with strong selfcontrol and restrained eating.

\section{Acknowledgments}

The research was funded by the EFOP-3.6.1-16-2016-00008 tender entitled "Developing smart life science technologies, methodologies and applications and creating innovative processes and services built on the knowledge base of Szeged".

\section{Bibliography}

1. Ainslie, G. (1975). Specious reward: a behavioral theory of impulsiveness. Psychol. Bull. 82, pp. 463-496

2. Bailly, N., Maitre, I., Amanda, M., Hervé, C. \& Alaphilippe, D. (2012). The Dutch Eating Behaviour Questionnaire (DEBQ). Assessment of eating behaviour in an aging French population. Appetite, 59(3), pp. 853-858.

3. Berns, G. S., Laibson, D., \& Loewenstein, G. (2007). Intertemporal choice--toward an integrative framework. Trends In Cognitive Sciences, 11(11), pp. 482-488.

4. Bertrams, A. \& Dickha, O. (2017). Messung dispositioneller SelbstkontrollKapazitat: Eine deutsche Adaptation der Kurzform der Self-Control Scale (SCSK-D). Diagnostica. 55 (1), pp. 2-10.

5. Black, A., D’Onise, K., McDermott, R., Vally, H., O’Dea, K. (2017). 'How effective are family-based and institutional nutrition interventions in improving children's diet and health? A systematic review. BMC Public Health, 17 (1) pp. 818.

6. Bölcskei V. (2009). Az intertemporális döntések viselkedési közgazdaságtani modelljeinek áttekintése. Közgazdasági Szemle, 56 (11), pp. 1025-1040.

7. Brevers, D., Foucart, J., Verbanck, P. \& Turel, O. (2017). Examination of the validity and reliability of the French version of the Brief Self-Control Scale. Canadian Journal of Behavioural Science. 49 (4), pp. 243-250.

8. Calvo D., Galioto R., Gunstad J. \& Spitznagel M. (2014). Uncontrolled eating is associated with reduced executive functioning. Clin Obes. 4(3), pp.172-179.

9. Cebolla, A., Barrada, J. R., van Strien, T., Oliver, E. \& Baños, R. (2014). Validation of the Dutch Eating Behavior Questionnaire (DEBQ) in a sample of Spanish women. Appetite, 73, pp. 58-64.

10. Danielsen, K. K., Svendsen, M., Mæhlum, S. \& Sundgot-Borgen, J. (2013). Changes in body composition, cardiovascular disease risk factors, and eating behavior after an intensive lifestyle intervention with high volume of physical activity in 
severely obese subjects: a prospective clinical controlled trial. Journal of obesity, pp. 325-464.

11. Drabik, P., Rehak, R., Vernerova, D., \& Kukura, M. (2020). Rational Consumer in the Context of Environmental Protection. Ekonomicky casopis, 68(10), 1081-1104

12. Elster, J. (2001): A társadalom fogaskerekei. Magyarázó mechanizmusok a társadalomtudományokban. Osiris Kiadó, Budapest.

13. Finkelstein, E., Ruhm, C. J., Kosa K. M. (2005). Economic Causes and Consequences of Obesity. Annual Review of Public Health. (26) pp. 239-257.

14. Friedman, M. (1986). A pozitív közgazdaságtan módszertana. In Riesz M. (szerk.): Infláció, munkanélküliség, monetarizmus: válogatott tanulmányok. Közgazdasági és Jogi Könyvkiadó, Budapest.

15. Fudenberg, D. \& Levine, D. K. (2006). A Dual-Self Model of Impulse Control. The American Economic Review, 96(5), pp. 1449-1476.

16. Garner, D. M. \& Garfinkel, P. E. (1979). The Eating Attitudes Test: an index of the symptoms of anorexianervosa. Psychological Medicine, 9, pp. 273-279.

17. Golovics J. (2015). Korlátozott racionalitás és altruizmus: behaviorizmus a közgazdaság-tudományban. Hitelintézeti Szemle. 14 (4) pp. 158-170.

18. Gul, F. \& Pesendorfer, W. (2001): Temptation and Self Control. Econometrica, 69 (6), pp. 1403- 1436.

19. Hámori, B. (1998): Érzelemgazdaságtan. A közgazdasági elemzés kiterjesztése. Kossuth Kiadó, Budapest.

20. Herman, C. P. \& Polivy, J. (1975). Anxiety, restraint, and eating behavior. Journal of abnormal psychology, 84 (6) pp. 666-672.

21. Herman, C. P. \& Polivy, J. (1980). Restrained eating. In: Stunkard, A. J. (szerk.): Obesity, pp. 208-225.

22. Huszka P. \& Dernóczy-Polyák A. (2015). Táplálékod legyen egészséged élelmiszer fogyasztási szokások vizsgálata a fiatalok körében. In: EMOK - XXI. Országos Konferencia Tanulmánykötet - Marketing hálózaton innen és túl.

23. Jones, B. D. (1999). Bounded Rationality'. Annual Review of Political Science. 2 (1) pp. 297-321.

24. Lakdawalla, D. \& Philipson, T. (2002). The Growth of Obesity and Technological Change: A Theoretical and Empirical Examination. NBER Working Papers

25. Lippai L. (2012). A testalkat jelentősége a gazdaságban. In: Hámori B., -Vajda B. Tóth L. - Derecskei,A. - Prónay Sz. (szerk.): Érzelmek és indulatok a gazdaságban. Szeged: Szegedi Tudományegyetem GTK. pp. 303-321.

26. Lippai, L. (2010). Az önkontroll szerepe és jelentősége az intertemporális fogyasztói döntésekben, Doktori Értekezés

27. McFadden, D. (1999): Rationality for Economists? Journal of Risk and Uncertainty. $19(1-3)$

28. Moreira, G. S. X., Mota, D. C. L., Lorenzato, L.,Kakeshita, I. S., Costa, T. M. B. \& Almeida, S. S. (2017). Transcultural Adaptation Procedures for the Dutch Eating Behavior Questionnaire (DEBQ) for Brazil. Avaliçãao Psicológica, 16 (4), pp. 426435.

29. Mulvaney, S. \& Lee, J. (2017), Motivating Health Behaviors in Adolescents Through Behavioral Economics. JAMA Pediatrics. 171 (12) pp. 1145-1146.

30. O'Donoghue, T. \& Rabin, M. (2006). Optimal sin taxes, Journal of Public Economics, 90 (10-11), pp. 1825-1849.

31. Ozdenoren, E., Salant, S. \&Silverman, D. (2006). Willpower and the Optimal Control of Visceral Urges. NBER Working Paper, 12278. Available at: https:// www.nber.org/papers/w12278 
32. Park, M. H., Falconer, C., Viner, R. M. \& Kinra, S. (2012). The impact of childhood obesity on morbidity and mortality in adulthood: a systematic review. Obesity reviews: an official journal of the International Association for the Study of Obesity, 13(11), pp. 985-1000.

33. Reilly, J. J. \& Kelly, J. (2011). Long-term impact of overweight and obesity in childhood and adolescence on morbidity and premature mortality in adulthood: systematic review. International Journal of Obesity, 35 (7), pp. 891-898.

34. Simon, H. A. (1986). Rationality in Psychology and Economics. The Journal of Business. 59 (4) pp. 209-224.

35. Statisztikai tükör, KSH (2017). Az egészségügyi kiadások alakulása Magyarországon 2010-2015

36. Stunkard, A. J. \& Messick, S. (1985). The three-factor eating questionnaire to measure dietary restraint, disinhibition and hunger. Journal of Psychosomatic Research, 29 (1), pp. 71-83.

37. Stutzer, A. \& Frey, B. S. (2006). What Happiness Research Can Tell Us About SelfControl Problems And Utility Misprediction, Institute for Empirical Research in Economics Working Papers

38. Székely, M. (2003). A fogyasztói magatartás alapjai: a lélek- és a gazdaságtan alapfeltevései a fogyasztásról' in Gazdaságpszichológia, szerk. Hunyady, Gy. és Székely, M., Osiris Kiadó, Budapest

39. Tangney, J. P., Baumeister, R. F. \& Boone, A. L. (2004). High Self-Control Predicts Good Adjustment, Less Pathology, Better Grades, and Interpersonal Success. Journal of Personality, 72 (2), pp. 271-322.

40. Unger, A., Bi, C., Xiao, Y. \& Ybarra, O. (2016). The revising of the Tangney SelfControl Scale for Chinese students. Psychology Chinese Journal. 5 (2), pp. 101-116.

41. van Strien T., Konttinen H., Homberg JR., Engels RC. \& Winkens LH (2016). Emotional eating as a mediator between depression and weight gain. Appetite. 100, pp. 216-224

42. Vázquez, F. \& Torres-Iglesias, A. (2012): Behavioral and Psychosocial Factors in Childhood Obesity. Childhood Obesity, pp. 143-166

43. Westenhoefer, J., Engel, D., Holst, C., Lorenz, J., Peacock, M., Stubbs, J., Whybrow, S. \& Raats, M. (2013). Cognitive and weight-related correlates of flexible and rigid restrained eating behaviour. Eating Behaviors, 14 (1), pp. 69-72.

44. Wu, S., Cai, T. \& Luo, X. (2017). Validation of the Dutch Eating Behavior Questionnaire (DEBQ) in a sample of Chinese adolescents. Psychology, Health \& Medicine, 22 (3), pp. 282-288.

\section{Correspondence address:}

Dalma Pető, PhD. student, Institute of Business Studies, Faculty of Economics and Business Studies, University of Szeged, Kálvária street 1., Szeged, Hungary, email: peto. dalma@eco.u-szeged.hu 